\title{
EDITORIAL
}

\section{An Exigency for Ice Core Studies to Determine Spatio-temporal Vari- ability in Moisture Sources and Impact of Black Carbon - Mineral Aerosols on the Himalayan Glaciers}

\author{
S. Nawaz Ali ${ }^{*}$ Anil D. Shukla ${ }^{2}$ \\ 1. Birbal Sahni Institute of Palaeosciences, Lucknow, 226007, India \\ 2. Physical Research Laboratory, Ahmedabad, 380009, India
}

\section{ARTICLE INFO}

Article history

Received: 13 August 2021

Accepted: 13 August 2021

Published Online: 16 August 2021

Himalayan glaciers- the store house of fresh water outside the polar region contributes $\sim 45 \%$ of the total river flow by glacial melt in the Indus, Ganga and Brahmaputra watersheds which supports the livelihood of $\sim 500$ million people ${ }^{[1]}$. The sustainability of these rivers is being questioned because of the growing evidences of accelerated glacier retreat in the recent decades, which is expected to have cascading effects on the mountainous areas and their surrounding lowlands. The rapid melting of Himalayan glaciers reveals their sensitivity to ongoing changes in climate dynamics, and if the current trend continues, rivers that rely heavily on snow/ice melt are expected to suffer hydrological disruptions to the point where some of the most populous areas may 'run out of water' during the dry season ${ }^{[2,3]}$. Therefore, efforts are being made to study the glacier mass balance trends in order to understand the patterns and causes of recent recessional trend. Despite their importance, the absence of long-term mass-balance and remote sensing data restricts our knowledge of the Himalayan glaciers' sensitivity/ response to climate change. Furthermore, such studies may be insufficient unless are compared to long-term glacier fluctuations (millennial and multi-millennial time scales), which aid in better understanding the natural trends of and human impacts on climate change, as well as assessing the causes and possible future of contemporary shrinking glaciers. This will also improve our understanding of past glacier behaviour in the context of primary causes of glacier change, which is critical for water resource management and understanding climate variability in high alpine areas where alternative proxy climate archives are typically scarce. Therefore, it is pertinent to pool our scientific resources and energy (i) towards understanding the Himalayan glaciers' feeders (precipitation sources) and how they changed over time (geological and historical), as well as the causes of glaciers recession, one of which has been identified as (ii) black soot (carbon) in aerosol pollution.

*Corresponding Author:

S. Nawaz Ali,

Birbal Sahni Institute of Palaeosciences, Lucknow, 226007, India; Email: snawazali@gmail.com 
Identifying the temporal changes in moisture sources: Glaciers in the Himalaya owe their existence to the precipitation brought by the two important weather systems viz. The Indian Summer Monsoon System (ISM) which forms a major component of the larger Asian Monsoon System and the mid-latitude westerlies. The ISM system is rooted in the larger atmospheric phenomenon with 1) the seasonal migration of seasonal migration of the Inter-tropical Convergence Zone (ITCZ), which is mainly governed by the seasonal variation of the latitude of maximum insolation ${ }^{[4,5]}$, and 2) the seasonal reversal of winds, governed by the annual cycle of solar radiation interacting with different heat capacities of the Tropical Ocean and land areas (meridional pressure gradient) resulting in differential heating ${ }^{[6,7]}$. Whereas the maximum precipitation across the western Himalaya occurs in combination with westerlies, which are synoptic weather systems that propagate eastward from the Mediterranean region towards South Asia and are strengthened during periods of ice sheet expansion.

Being the most dominant weather system, the contemporary relationship between the ISM and the Himalayan snow cover has been the subject of extensive scientific research. In the recent years numerous studies investigated the relationship between ISM rainfall and snow cover over Himalaya. The results show that winter and spring snow cover over western Eurasia (eastern Eurasia) is negatively (positively) correlated to the subsequent summer monsoon ${ }^{[8]}$. Enhanced mid-latitude westerlies (westerly disturbances) that develop over the Mediterranean Sea/ Black Sea/Caspian Sea as extratropical frontal systems, account for snow at the higher elevations of the NW and Central Himalaya in the winter ${ }^{[9]}$. In comparison, glaciers in the eastern Himalaya get the majority of their precipitation during the summer SW monsoon months, which also coincide with the melting season. As a result, the western and northwest glaciers are winter accumulation type, whereas their eastern counterparts are summer accumulation type. These inferences are drawn based on limited mass balance studies skewed towards summer months and scanty isotopic data obtained on snow and glacial melt. Thus, above these propositions are highly debatable and inconclusive.

Here it is worth mentioning that the Himalayan topography plays a significant role in modulating the relative influence of the ISM and westerly disturbances along and across the Himalaya. These weather systems define the magnitude and spatial extent of the glaciers in the Himalayan orogen ${ }^{[10-12]}$. The deep time inferences (millennial and multi-millennial time scales) regarding the contributory role of the ISM and westerlies in nourishing the Himalayan glaciers are largely drawn based on the chronologically constrained moraine stratigraphy and their correlation with the standard climatic curves. The study although provides a broad idea about temporal changes in moisture sources, however, because of strong chronometric dependency, the inferences about moisture sources would remain tentative and speculative. In view of this, the credible inferences about the spatial and temporal variability in the source of moisture towards the growth of Himalayan glacier should use the long (time) ice core data implying the isotopic fingerprinting of the ice core time slices.

The stable isotope ratios of oxygen $\left(\delta \mathrm{O}^{18}\right)$, hydrogen $\left(\delta^{2} \mathrm{H}\right)$ and deuterium excess ( $\mathrm{d}$-excess) have been widely used for tracking the moisture sources and transport pathways of moisture laden air masses. The stable isotopic studies have also been used in quantifying the relative contributions of different moisture sources as well as reconstructing past climate variability ${ }^{[13,14]}$. Ice cores recovered from the northern slopes of Himalaya and Tibetan Plateau have provided some of the best high resolution records of past climate in the region. The stable isotope analyses of winter snow cover and summer rainfall along transect from the NW Himlayan (Ladakh) to the eastern Himalaya (Arunachal Pradesh) will help in establishing the spatial influence of the moisture sources. The relative contributions of the moisture source(s), their temporal variability and the corresponding growth/ shrinkage (advance/retreat) of glaciers can only be addressed through long (time) ice core data implying the isotopic fingerprinting of the ice core time slices.

(ii) Impact of black soot (carbon) and mineral aerosol: Black soot in aerosol pollution can warm the troposphere, perhaps leading to surface melt ${ }^{[15,16]}$. Absorption is primarily caused by the black carbon (BC), whereas organic carbon (OC) absorbs mainly in the UV and slightly in the visible range. Black soot incorporated in snowflakes darkens snow and ice surfaces, increasing surface melt ${ }^{[17,18]}$. The extensive black soot aerosols might be lofted to the high Himalaya and incorporated in snowflakes, which when descending on the glaciers darken their surface. The presence of $\mathrm{BC}$ and $\mathrm{OC}$ in Himalayan snow and ice has inspired preliminary research on the subject, and its function in glacier melting has yet to be thoroughly assessed ${ }^{[19]}$.

According to studies, soot may be the second most important component of global warming, after carbon dioxide, in terms of direct radiative forcing. Soot is anthropogenic in origin (combustion of biomass and fossil fuels); mineral aerosols, on the other hand, are naturally occurring continental dust from dryland areas carried by the winds. There are evidences to suggest that air-temperature trend over the Himalayan region has accelerated (between 
0.15 and $0.3 \mathrm{~K} /$ decade) in recent decades. Unlike soot, the mineral aerosols are anticipated to have a negative forcing at the Earth's surface as they tend to scatter or absorb insolation and thus affect the radiation budget. Among aerosol constituents, black carbon (BC) is a key absorbing aerosol constituent formed by incomplete combustion of biomass, biofuel, and fossil fuel. The concentrations of aerosol are increasing over the Indian subcontinent and are expected to serious implications on the neighboring Himalayan glaciers through snow albedo reduction and accelerated melting of snow ${ }^{[20]}$.

As such studies -till date- remain elusive from the Indian Himalaya, rational explanations for the complex and varying pattern of glacier response to climate variables across different sectors remain a source of contention. We are aware that there are logistical constraints as well as problems associated with ice core retrieval due to the less dense nature of Himalayan glacier ice, which prevents core recovery, but we must consider trying methodology so that some key glaciers located in climatically strategic locations can be drilled. Therefore, to begin with we must occupy the glaciers located in the climate sensitive transitional climatic zone in the Himalaya which are influenced by both the westerlies and the ISM.

\section{References}

[1] World Resources Institute - WRI Annual Report (2003). https://www.wri.org/wri-annual-report-2003.

[2] Bolch, T., Kulkarni, A., Kääb, A., Huggel, C., Paul, F., Cogley, J.G., Frey, H., Kargel, J.S., Fujita, K., Scheel, M. and Bajracharya, S., 2012. The state and fate of Himalayan glaciers. Science, 336(6079), pp.310-314.

[3] Maurer, J.M., Schaefer, J.M., Rupper, S. and Corley, A., 2019. Acceleration of ice loss across the Himalayas over the past 40 years. Science advances, 5(6), p.eaav 7266.

[4] Riehl, H., 1979. Climate and weather in the tropics; Academic Press, San Diego.

[5] Gadgil, S., 2003. The Indian monsoon and its variability. Annual Review of Earth and Planetary Sciences, 31(1), pp.429-467.

[6] Webster, P.J., 1987, The elementary monsoon; In: Monsoons (eds) Fein, J.S. and Stephens, P.S., 3-32, (New York: Wiley).

[7] Tada, R., Zheng, H. and Clift, P.D., 2016. Evolution and variability of Asian monsoon and its potential linkage with the Himalayas-Tibetan Plateau uplift. Progress in Earth and Planetary Science, 3.

[8] Wu, Z., Li, J., Jiang, Z. and Ma, T., 2012. Modulation of the Tibetan Plateau snow cover on the ENSO tele- connections: From the East Asian summer monsoon perspective. Journal of Climate, 25(7), pp.2481-2489.

[9] Cannon, F., Carvalho, L.M., Jones, C. and Norris, J., 2016. Winter westerly disturbance dynamics and precipitation in the western Himalaya and Karakoram: a wave-tracking approach. Theoretical and Applied Climatology, 125(1), pp.27-44.

[10] Benn, D.I. and Owen, L.A., 1998. The role of the Indian summer monsoon and the mid-latitude westerlies in $\mathrm{Hi}$ malayan glaciation: review and speculative discussion. Journal of the Geological Society, 155(2), pp.353-363.

[11] Ali, S.N. and Juyal, N., 2013. Chronology of late quaternary glaciations in Indian Himalaya: a critical review. Journal of the Geological Society of India, 82(6), pp.628-638.

[12] Sharma, S. and Shukla, A.D., 2018. Factors governing the pattern of glacier advances since the Last Glacial Maxima in the transitional climate zone of the Southern Zanskar Ranges, NW Himalaya. Quaternary Science Reviews, 201, pp.223-240.

[13] Jouzel, J., Froehlich, K. and Schotterer, U., 1997. Deuterium and oxygen-18 in present-day precipitation: data and modelling. Hydrological Sciences Journal, 42(5), pp.747-763.

[14] Ali, S.N., Sharma, A., Agrawal, S., MG, Y., RA, J., Dubey, J. and Morthekai, P., 2020. Oxygen and deuterium isotope characteri stics of Teesta river catchment from Sikkim Himalaya, India: Implications of different moisture sources. Geochemical Journal, 54(5), pp.327-336.

[15] Hansen, J., Sato, M., Ruedy, R., Lacis, A. and Oinas, V., 2000. Global warming in the twenty-first century: An alternative scenario. Proceedings of the National Academy of Sciences, 97(18), pp.9875-9880.

[16] Jacobson, M.Z., 2001. Strong radiative heating due to the mixing state of black carbon in atmospheric aerosols. Nature, 409(6821), pp.695-697.

[17] Warren, S.G. and Wiscombe, W.J., 1985. Dirty snow after nuclear war. Nature, 313(6002), pp.467-470.

[18] Clarke, A.D. and Noone, K.J., 2007. Soot in the Arctic snowpack: A cause for perturbations in radiative transfer. Atmospheric Environment, 41, pp.64-72.

[19] Xu, B., Cao, J., Hansen, J., Yao, T., Joswia, D.R., Wang, N., Wu, G., Wang, M., Zhao, H., Yang, W. and Liu, X., 2009. Black soot and the survival of Tibetan glaciers. Proceedings of the National Academy of Sciences, 106(52), pp.22114-22118.

[20] Das, S.K., Dobhal, D.P. and Juyal, N., 2010. Variability of aerosol optical depth and recent recessional trend in Dokriani Glacier, Bhagirathi Valley, Garhwal Himalaya. Current Science, pp.1816-1821. 